\title{
INVESTIGATE OF VIRULENCE- GENES OF PASTEURELLA MULTOCIDA TYPES AND ANTIBIOTIC SUSCEPTIBILITY IN BUFFALOES IN MARSHES OF SOUTH OF IRAQ
}

\author{
${ }^{1}$ Ibrahim Abbas Mohammed, ${ }^{2}$ Jalil Abed Gatie \\ $\mathbf{1 , 2} \mathbf{2}_{\text {Veterinary }}$ Hospital in Thi Qar. Vet. Directorate .Ministry of agriculture - Iraq
}

\begin{abstract}
This study was conducted to investigate the incidence of Pasteurella multocida in buffaloes in south of Iraq. A total 393 of different ages and sexes, were clinically examined. Nasal swabs and blood samples were taken. Enrich and Selective medias ,biochemical tests and Gram stain were used. also used antibiotic susceptibility. All positive cases confirmed by polymerase chain reaction with specific primer to $P$. multocida then use specific primers to detect P.multocida A,B. Also use specific primers to detect some virulence gene ( $\mathrm{pfhA}$; nanH ; ompA; hgbA).Prevalence of $P$. multocida types in marshes area which it appear 35 samples $35 \%$ to type $A$ and it significant variation at $(\mathrm{P} \leq 0.05)$ than types (B) which found 65 samples $65 \%$ also it significant variation. Capsular typing of 100 isolates in marshes appeared $35(35 \%)$ to type A, $65(65 \%)$ to type B with significantly variation between types . Distribution of virulence- genes appeared 75 (75\%) to ompA, hgbA 59 (59\%) , nanH 46 ( $46 \%)$ and pfhA 33(33\%) with significantly variation between genes .No significant variation of prevalence of virulencegenes between infected and non-infected. Also prevalence of Pasteurella multocida virulence- genes which it appear 49(74.2\%);26(76.4\%)to ompA , 41(62.1), 18(52.9) to hgbA ; 27(40.9), 19(55.9) to nanH and 20(30,3), 13(38.3) to pfhA for diseased and non diseased respectively .Prevalence of P.multocida virulence- genes appeared 25(71.4); 50(76.9); to ompA , 18(51.4), 41(63.1); to hgbA ; 16(45), 30(47.6) to nanh and 16(45.7), 17(27.0); to pfhA for type A and type B respectively.

The antibiotics susceptibility of 52 isolated which from 25 type B , 25 type A and showed that : Cefotaxime, Cefitrixone, Azithromycin and Tilmicosin founded $100 \%$ susceptibility ,followed by Chloromphinocol as $96-92 \%$, Tetracycline $40-32 \%$ while Ampicilline $32-28 \%$.

Conclusions of present study are : P. multocida endemic in buffaloes in south of Iraq. Recoded of virulence genes of $P$. multocida in buffaloes in Iraq. Cefotaxime, Cefitrixone, Azithromycin and Tilmicosin are the best choice to treatment. PCR assay is best technique to diagnosis and detect.
\end{abstract}

Keywords: Pasteurella Multocida. Virulence- Genes . Antibiotic susceptibility . Buffaloes . Marshes 


\section{https://jam.utq.edu.iq/index.php/main D Doi: https://doi.org/10.54174/UTJagr.Vo9.N1/03}

\section{Introduction}

Pasteurella multocida, a Gram negative pathogenic bacteria and it can produce many types of diseases to many species of animals. hemorrhagic septicemia(HS) are important economic disease caused by $P$. multocida because it fatal to buffaloes in many cases, it also causes(HS) in cattle but less than buffaloes and it is also etiological agent of pneumonia in bovine , , (Ara et al.,2016;).

$P$. multocida is found as a normal flora in respiratory tract but under stress or other infection like para influenza virus infection ,this will lead to enhance P. multocida infection so( HS) outbreak mostly occur in raining season (; Ahmed et al.,2015; Constable et al.,2017)

Clinical finding of (HS) which caused by P..multocida type B:2 or E:2 (B in Asia, E in Africa ) strains appear as rapid increase of temp. , difficult in respiration ,at same time serious then become mucoid discharge from nasal orifices , mouth frothing, and submandibular edema was observe, then after hrs. animal will be recumbence then death in less than 7 hours. While the infection with $P$. multocida type A: mostly include respiratory disease.(Rhinitis to Pneumonia. ) and may death in some cases and it called bovine resp. disease.(BRD) but in peracute cases suddenly death with clinical finding Septicemia is a hallmark in all disease circumstance. incubation period between 72 hours to 5 days (OIE , 2012).

There are Several pathogen-specific factors in P. multocida act with host to cause infection . These factors called virulence- genes, and they are very important for pathogenesis, resistant to antibiotic, and vaccine development (Khamesipour et al., 2014)

The nonspecific use of the antimicrobial to treatment any bacterial infection as a randomly treatment of nonspecific dose or nonspecific period this will be induce antimicrobial resistant. also there are many genes of $P$. multocida have resistant act to many antimicrobial. This lead to an increase in dose of antibiotic or replace treatment with new generation of antibiotics and this lead to an increase in the cost of productive animals. Also the antimicrobial resistant may transfer through milk or other animal product to human. and this important point ( Khamesipour et al., 2014; El Garch et al., 2016 )

\section{Aims of study :}

1. Investigate the presence of P.multocida in buffaloes in marshes in south of Iraq.

2. Confirmation of P. multocida by using conventional PCR technique and genotyping by genotypes specific primers for (genotype A, B).and detect some virulence genes

3. Study of antimicrobial susceptibly from isolations

\section{II.Material and methods}

Nasal swabs were taken from 393 buffaloes, nasal swabs were added to sterile tubes containing brain heart infusion broth(BHIB) then transported to the laboratory in ice box containers as fast as (Cowan, 2003) 
ISSN Onlin:2708-9347, ISSN Print: $2708-9339$ Volume 9, Issue 1 (2020) PP 24-37

https://jam.utq.edu.iq/index.php/main D Doi: https://doi.org/10.54174/UTJagr.Vo9.N1/03

Where $2.5 \mathrm{ml}$ of blood was taken from jugular vein by EDTA tubes just from diseased buffaloes, blood samples added to sterile tubes containing (BHIB) then transported to the laboratory like nasal swabs

The tubes of (BHIB) were put in incubator at $37 \mathrm{C}^{\circ}$ for $18-24 \mathrm{hrs}$. then subculture on blood agar as a enrichment media for 18-24 hrs at $37 \mathrm{C}^{\circ}$ for another 18-24 hrs., then swabs were taken from blood agar (BA) and sub cultured it on blood agar (BA)another time ( but as selective media), and put in incubator at $37 \mathrm{C}^{\circ}$ to $18-24 \mathrm{hrs}$.After that, sub cultured on MacConkey agar to $18-24 \mathrm{hrs}$ at $37 \mathrm{C}^{\circ}$. The colonies were examined by naked eye to detect the shape, size and color of colony P. multocida on blood agar, also the haemolysis effect on the blood agar, in additional to detect the growth on MacConKey agar.After that colonies were examined microscopically by Gram stain by smear from pure colony from blood agar put it on a slide, then stained it according to procedure of Gram stain .then biochemical tests (Urease test/ Indol test / TSI test / Oxidase test / Catalase test/) (Quinn et al., 2011)

PCR assay was performed for detection and genotyping of $P$. multocida based on amplification of capsular biosynthesis gene and detection of virulence genes this protocol was producing by (Townsend et al., 1998)

The test isolates were subjected to in vitro antibiotic sensitivity as per the method described by Bauer et al. (1966)

\section{Statistical analysis:}

Statistical analysis were done by Chi-square test between parameters.

\section{Results}

The study recorded two form of colonies from freshly isolated of $P$. multocida were roughly and small and other colonies appeared mucoid and large ,but color was greyish, glistening, translucent, approximately one mm in diameter on blood agar after $24 \mathrm{~h}$ incubation at $37 \mathrm{C}^{\circ}$. Gram staining revealed, Gram negative, short and ovoid coccobacilli .

Also found that biochemical tests results were oxidase, catalase, indole, nitrate reduction and ornithine decarboxylase positive and urease negative. P. multocida didn't ingrowth on MacConkey agar and were found to be non-haemolytic on blood agar.

\section{Capsular PCR to detect $P$. multocida type}

The capsular PCR serotypes of $P$. multocida was successfully optimized and applied to confirm the serotypes of $P$. multocida. The reference strains of P.multocida serotype A, and B yielded the expected results in the capsular PCR serotypes - all strains of different serotypes gave the 460 bp band specific for $P$. multocida. The serotype A strain gave the 1,044 bp band characteristic of this serotype. Figure 1 . The serotype B reference strain gave the $760 \mathrm{bp}$ which are the expected results 
ISSN Onlin:2708-9347, ISSN Print: 2708-9339 Volume 9, Issue 1 (2020) PP 24-37

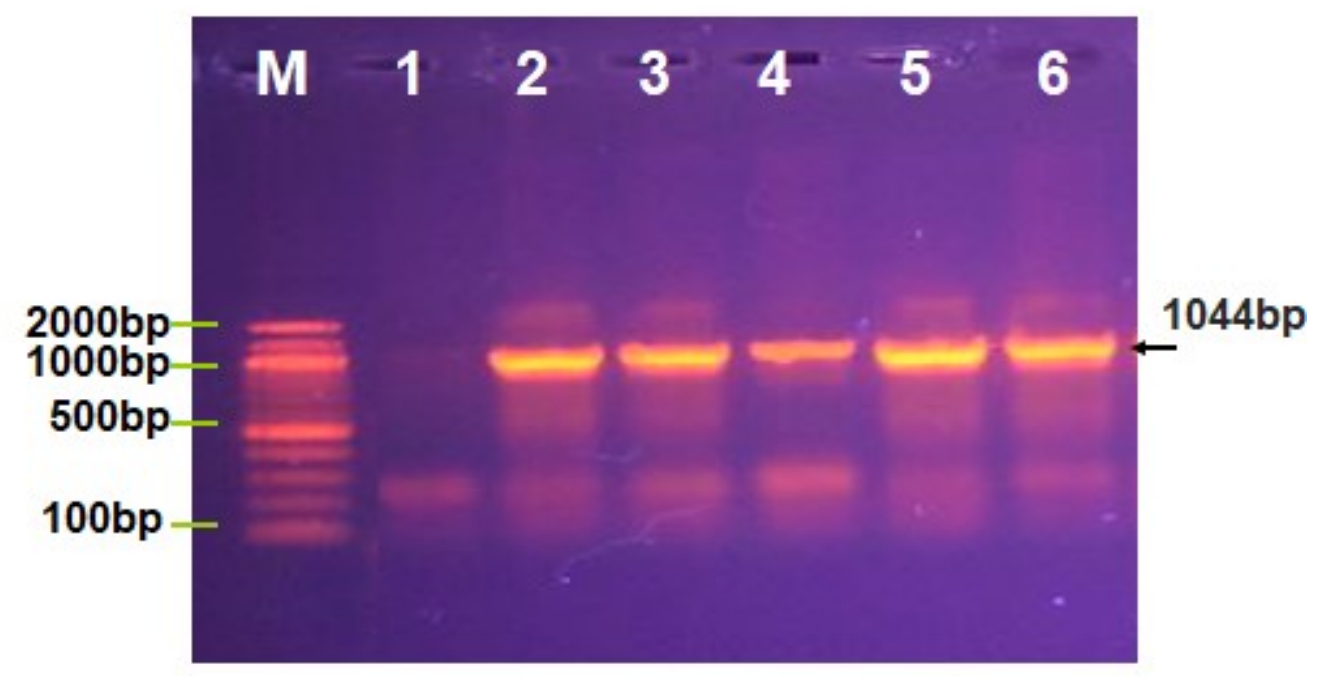

Figure(1): PCR product analysis of capsule genotype A in Pasteurella multocida isolates. Where M: marker (2000-100bp), lane (2-6) positive isolates at (1044bp) PCR product size.

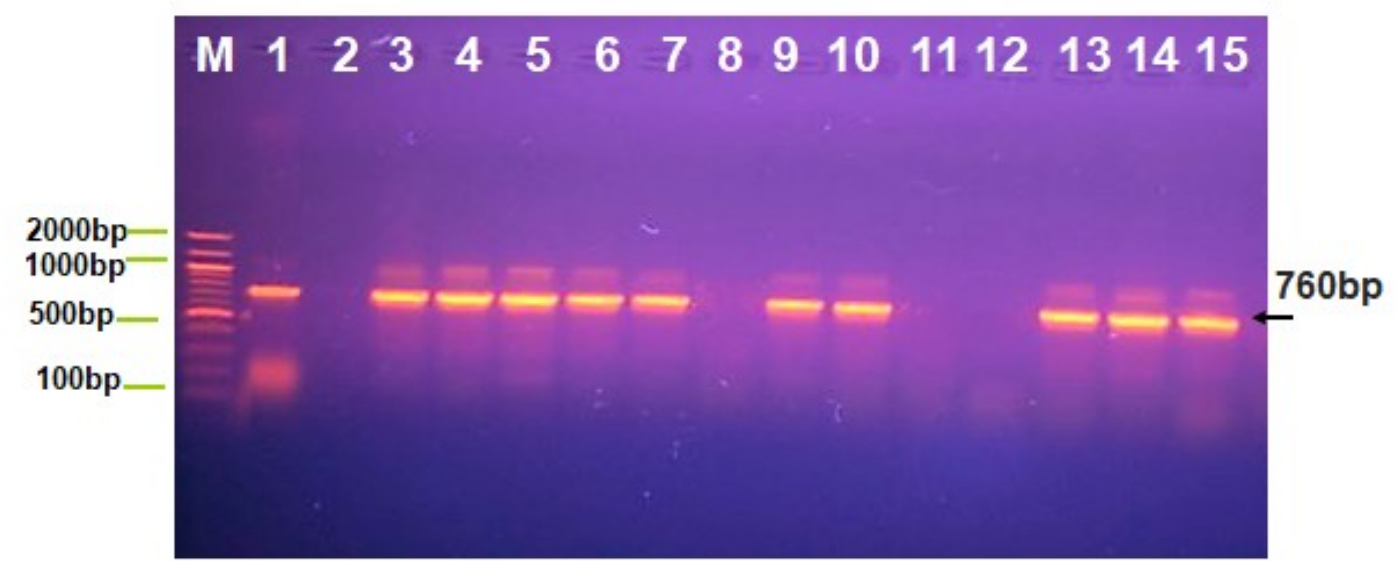

Figure (2): PCR product analysis of capsule genotype B in P. multocida isolates. Where M: marker (2000-100bp), lane $(2-7,9,10,13-15)$ positive isolates at (760bp) PCR product size.

\section{Prevalence of $P$. multocida types}

Prevalence of $P$. multocida types in marshes area which it appear 35 samples $35 \%$ to type $A$ and it significant variation at $(P \leq 0.05)$ than types $(B)$ which found 65 samples $65 \%$ also it significant variation at $(P \leq 0.05)$ Table (1).

Table (1) Prevalence of P. multocida types. 
ISSN Onlin:2708-9347, ISSN Print: 2708-9339 Volume 9, Issue 1 (2020) PP 24-37

\section{https://jam.utq.edu.iq/index.php/main $\quad$ Doi: https://doi.org/10.54174/UTJagr.Vo9.N1/03}

\begin{tabular}{|c|c|c|c|}
\hline & Total & Types (A) & Types (B) \\
\hline Samples & 100 & $35^{*}$ & $65^{\star}$ \\
\hline Prevalence & $100 \%$ & $35 \%$ & $65 \%$ \\
\hline
\end{tabular}

${ }^{*}$ Donates a significant variation at $(\mathrm{P} \leq 0.05)$

Also distribution of the capsular typing P. multocida isolates between type of sample and location of isolation and clinical sings appeared $(32,43)$ of type $(A),(B)$ respectively from nasal swabs of diseased buffaloes also showed ( 0,2 ) of type (A),(B), respectively from blood of diseased buffaloes . At same time appeared $(12,22)$ of type (A),(B)respectively from nasal swabs of health buffaloes

Table (2)the capsular typing of $\mathrm{P}$ multocida isolates distribution between type of sample and location of isolation and clinical sings

\begin{tabular}{|c|c|c|c|}
\hline Animals & Samples & Types (A) & Types (B) \\
\hline \multirow{2}{*}{$\begin{array}{l}\text { Diseased } \\
(66) \text { head }\end{array}$} & Nasal & 23 & $43^{*}$ \\
\cline { 2 - 4 } & Blood & 0 & $2^{*}$ \\
\hline \multirow{2}{*}{ Health (34)head } & Nasal & 12 & 22 \\
\cline { 2 - 4 } & Blood & 0 & 0 \\
\hline Total heads & & $35(35 \%)$ & $65(65 \%)$ \\
\hline
\end{tabular}

* Same heads isolated blood and nasal swabs

\section{Prevalence of virulence- genes of $P$. multocida types}

Prevalence of virulence- genes of $P$. multocida types in Marshes area which it appear 75 samples $75 \%$ to OMPA virulence- gene(Fig:3) and it significant higher at ( $\mathrm{P} \leq 0.05)$ than hgbA virulence- gene(Fig:4) who found 59 samples $59 \%$ also it significant higher at $(P \leq 0.05)$ than nanH virulence- gene (Fig:5) which it appear 46 samples $46 \%$. when pfhA virulence- gene (Fig:6) who found 33 samples $33 \%$ it significant lowest at $(P \leq 0.05)$ than other and Table. (3) 
ISSN Onlin:2708-9347, ISSN Print: 2708-9339 Volume 9, Issue 1 (2020) PP 24-37

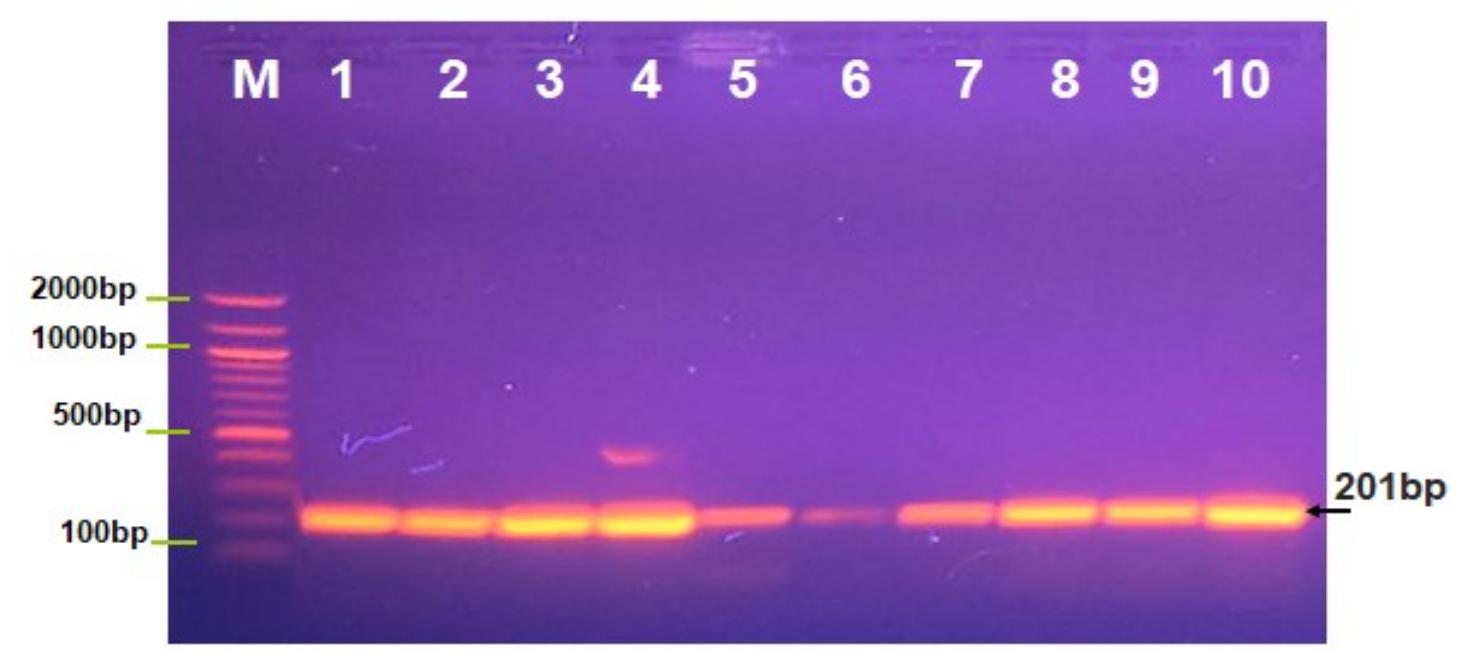

Figure (3): PCR product analysis of ompA gene in Pasteurella multocida isolates. Where M: marker (2000100bp), lane (1-10) positive ompA gene at (201bp) PCR product size.

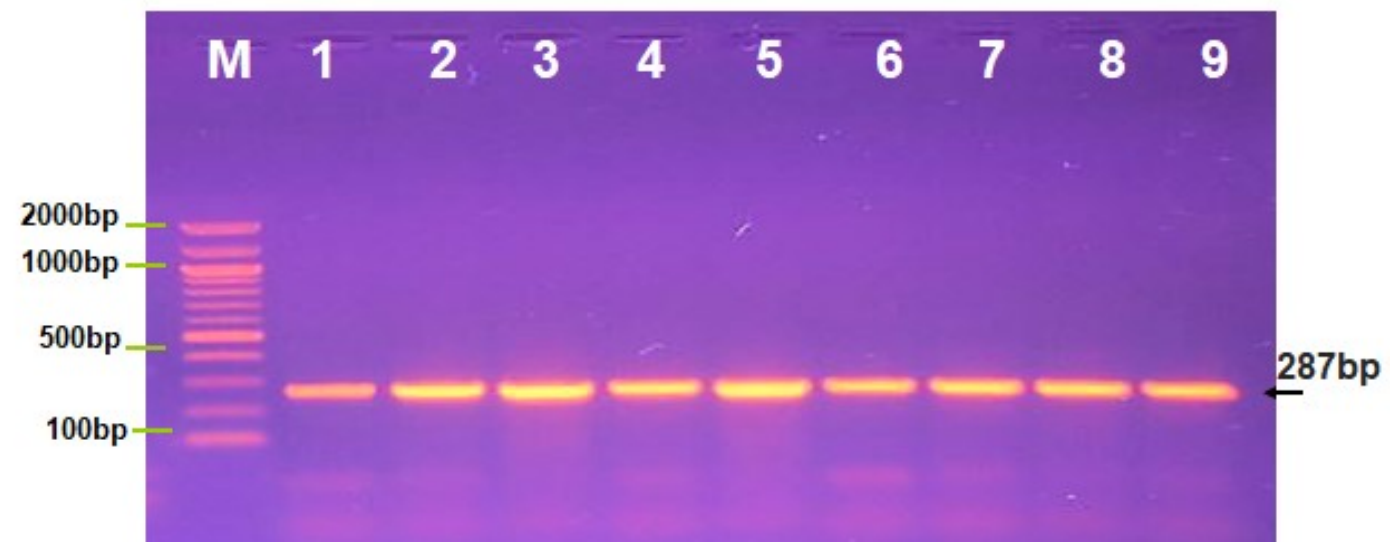

Figure (4): PCR product analysis of nanH gene in Pasteurella multocida isolates. Where M: marker (2000100bp), lane (1-9) positive nanH gene at (287bp) PCR product size. 
ISSN Onlin:2708-9347, ISSN Print: 2708-9339 Volume 9, Issue 1 (2020) PP 24-37

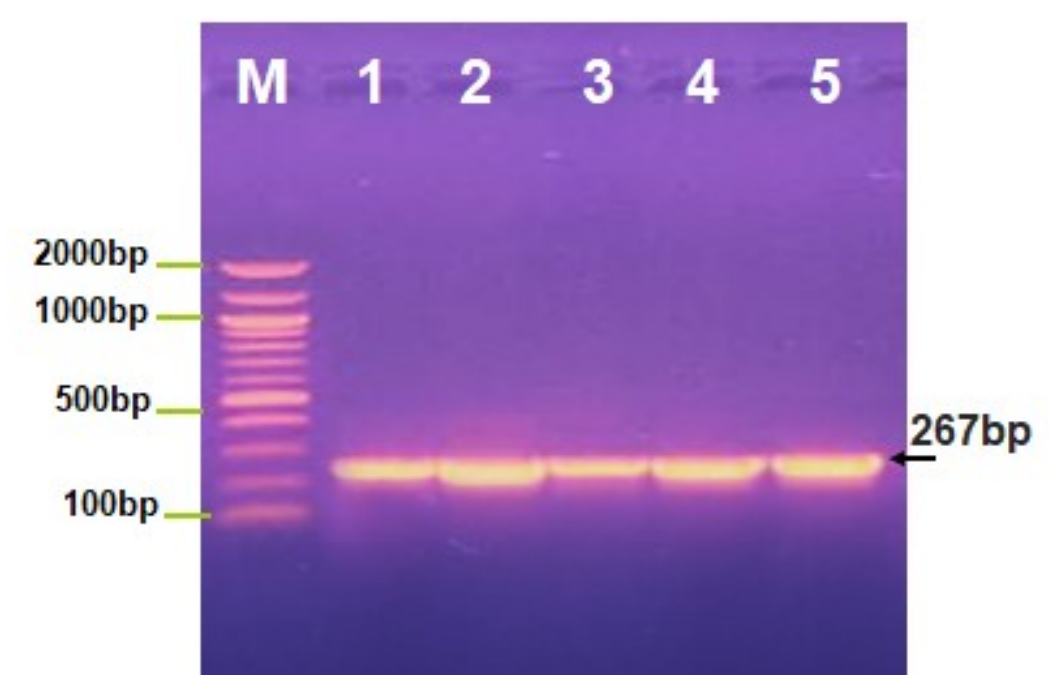

Figure (5): PCR product analysis of hgbA gene in Pasteurella multocida isolates. Where M: marker (2000-100bp), lane (1-5) positive hgbA gene at (267bp) PCR product size.

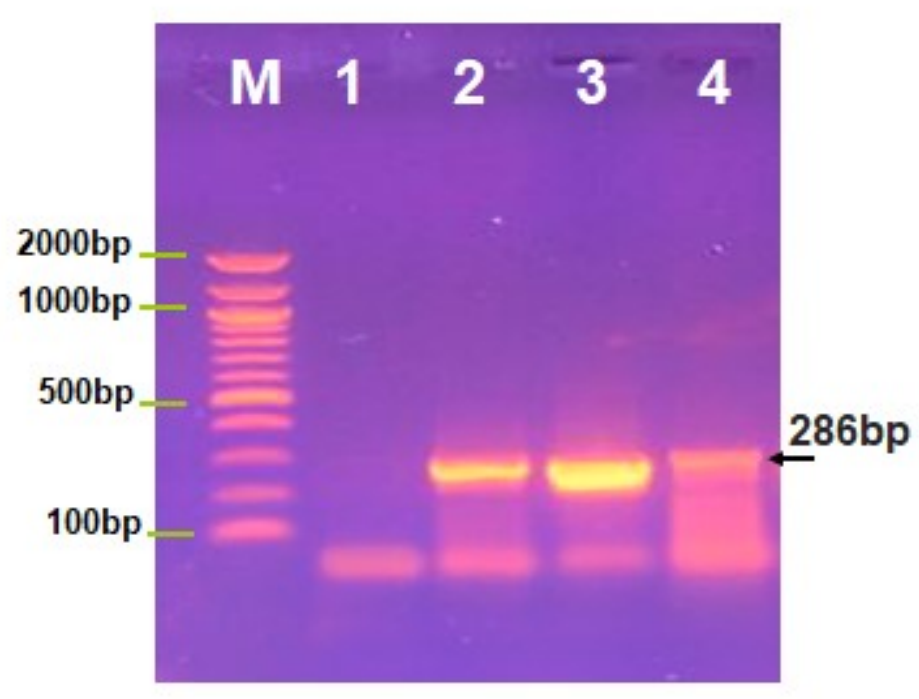

Figure (6): PCR product analysis of pfhA gene in Pasteurella multocida isolates. Where M: marker (2000-100bp), lane (2-4) positive pfhA gene at (286bp) PCR product size.

Table. (3) Prevalence of $P$. multocida virulence- genes

\begin{tabular}{|c|c|c|c|c|}
\hline No. & Virulence- genes & Samples & Prevalence & Mean \pm SE \\
\hline 1 & ompA & 75 & $75 \%$ & $0.75 \pm 0.07^{*}$ \\
\hline
\end{tabular}


ISSN Onlin:2708-9347, ISSN Print: 2708-9339 Volume 9, Issue 1 (2020) PP 24-37

https://jam.utq.edu.iq/index.php/main

Doi: https://doi.org/10.54174/UTJagr.Vo9.N1/03

\begin{tabular}{|c|c|c|c|c|}
\hline 2 & hgbA & 59 & $59 \%$ & $0.59 \pm 0.06^{\star}$ \\
\hline 3 & nanH & 46 & $46 \%$ & $0.46 \pm 0.05^{\star}$ \\
\hline 4 & pfhA & 33 & $33 \%$ & $0.33 \pm 0.04^{*}$ \\
\hline
\end{tabular}

${ }^{*}$ Donates a significant variation at $(\mathrm{P} \leq 0.05)$

Prevalence rate of virulence- genes of buffaloes according to clinical sings

Prevalence of $P$. multocida virulence- genes which it appear $49(74.2 \%) ; 26(76.4 \%)$ to ompA , 41(62.1), 18(52.9) to hgbA ; 27(40.9), 19(55.9) to nanH and 20(30,3),13(38.3) to pfhA for Diseased and Non Diseased respectively table (4).

Table (4) Showed prevalence rate of $P$. multocida virulence- genes of buffaloes according to clinical signs

\begin{tabular}{|c|c|c|c|c|c|}
\hline \multirow{2}{*}{ Clinically } & Samples & ompA(\%) & hgbA (\%) & nanH(\%) & pfhA(\%) \\
\hline Diseased & 66 & $49(74.2 \%)$ & $41(62.1 \%)$ & $27(40.9 \%)$ & $20(30,3 \%)$ \\
\hline $\begin{array}{l}\text { Non } \\
\text { Diseased }\end{array}$ & 34 & $26(76.4 \%)$ & $18(52.9 \%)$ & $19(55.9 \%)$ & $13(38.3 \%)$ \\
\hline Total & 100 & 75 & 59 & 46 & 33 \\
\hline
\end{tabular}

${ }^{*}$ Donates a significant variation at $(\mathrm{P} \leq 0.05)$

Prevalence rate of virulence- genes of buffaloes according to Types

Prevalence of $P$. multocida virulence- genes appeared 25(71.4); 50(76.9); to ompA , 18(51.4), 41(63.1); to hgbA ; 16(45), 30(47.6) to nanH and 16(45.7), 17(27.0); to pfhA for Type A and Type B respectively table (5).

Table (5) showed prevalence rate of $P$ multocida virulence- genes of buffaloes according to types 
ISSN Onlin:2708-9347, ISSN Print: 2708-9339 Volume 9, Issue 1 (2020) PP 24-37

https://jam.utq.edu.iq/index.php/main

Doi: https://doi.org/10.54174/UTJagr.Vo9.N1/03

\begin{tabular}{|c|c|c|c|c|c|}
\hline Clinically & Samples & ompA(\%) & hgbA (\%) & nanH(\%) & pfhA(\%) \\
\hline Type A & 35 & $\mathbf{2 5 ( 7 1 . 4 )}$ & $18(51.4)$ & $16(45)$ & $16(45.7)$ \\
\hline Type B & 65 & $\mathbf{5 0 ( 7 6 . 9 )}$ & $41(63.1)$ & $30(47.6)$ & $17(27.0)$ \\
\hline Total & 100 & $\mathbf{7 5}$ & 59 & 46 & 33 \\
\hline
\end{tabular}

${ }^{*}$ Donates a significant variation at $(\mathrm{P} \leq 0.05)$

\section{Sensitivity of antibiotic of $P$. multocida isolates}

Sensitive antibiotics of 25 isolates of serotype B and 25 isolates of serotype A (Table. 6,7) showed that : Cefotaxime , Cefitrixone, Azithromycin and Tilmicosin were found to be the high susceptible antimicrobial as $100 \%$ to serotype A and serotype B, followed by Chloromphinocol as $92 \%$ of serotype B isolates were susceptible to it and $96 \%$ of serotype $A$ isolates were susceptible to it , and Tetracycline $40 \%$ of serotype $B$ isolates were susceptible to it and $32 \%$ of serotype $A$ isolates were susceptible to it, while Ampicilline32 \%of serotype B isolates were susceptible to it and $28 \%$ of serotype $A$ isolates were susceptible to it, also at last vancomycin $0 \%$ of serotype $B$ isolates were susceptible to it and $0 \%$ of serotype $A$ isolates were susceptible to it.

Table.(6) Antibiotic susceptibility of $P$. multocida serotype B isolates

\begin{tabular}{|c|c|c|c|}
\hline \multirow[t]{2}{*}{ Anti-bacterial agents } & \multirow[t]{2}{*}{$\begin{array}{l}\text { No of total } \\
\text { serotype } \\
\text { isolates }\end{array}$} & \multicolumn{2}{|c|}{$\begin{array}{l}\text { Serotype B susceptibility to } \\
\text { antibiotic agents }\end{array}$} \\
\hline & & Susceptible & Resistant \\
\hline Tetracycline & 25 & $\begin{array}{l}10 \\
40 \%\end{array}$ & $\begin{array}{l}15 \\
60 \%\end{array}$ \\
\hline Ampicillin & 25 & $\begin{array}{l}8 \\
32 \%\end{array}$ & $\begin{array}{l}17 \\
68 \%\end{array}$ \\
\hline Cefitrixone & 25 & $\begin{array}{l}25 \\
100 \%\end{array}$ & $\begin{array}{l}0 \\
0 \%\end{array}$ \\
\hline Cefotaxime & 25 & $\begin{array}{l}25 \\
100 \%\end{array}$ & $\begin{array}{l}0 \\
0 \%\end{array}$ \\
\hline Azithromycin & 25 & $\begin{array}{l}25 \\
100 \%\end{array}$ & $\begin{array}{l}0 \\
0 \%\end{array}$ \\
\hline
\end{tabular}


ISSN Onlin:2708-9347, ISSN Print: $2708-9339$ Volume 9, Issue 1 (2020) PP 24-37

\section{https://jam.utq.edu.iq/index.php/main}

Doi: https://doi.org/10.54174/UTJagr.Vo9.N1/03

\begin{tabular}{|l|l|l|l|}
\hline Chloramphenicol & 25 & 23 & 2 \\
& & $92 \%$ & $8 \%$ \\
\hline Vancomycin & & 0 & 25 \\
& 25 & $0 \%$ & $100 \%$ \\
\hline Tilmicosin & 25 & 25 & 0 \\
\hline
\end{tabular}

Tab.(7) Antibiotic susceptibility of $P$. multocida serotype A isolates

\begin{tabular}{|l|l|l|l|}
\hline Anti-bacterial agents & \multicolumn{1}{|c|}{$\begin{array}{r}\text { Nof total } \\
\text { serotype } \\
\text { isolates }\end{array}$} & \multicolumn{2}{|c|}{$\begin{array}{c}\text { SerotypeA susceptibility to } \\
\text { antibiotic agents }\end{array}$} \\
\hline Tetracycline & & S & 17 \\
& 25 & $32 \%$ & $68 \%$ \\
\hline Ampicillin & 25 & 7 & 18 \\
\hline Cefitrixone & & $28 \%$ & $72 \%$ \\
\hline Cefotaxime & 25 & 25 & 0 \\
\hline Azithromycin & 25 & $100 \%$ & 0 \\
\hline Chloramphenicol & & 25 & $0 \%$ \\
\hline & 25 & 25 & 0 \\
\hline
\end{tabular}


ISSN Onlin:2708-9347, ISSN Print: $2708-9339$ Volume 9, Issue 1 (2020) PP 24-37

\section{https://jam.utq.edu.iq/index.php/main D Doi: https://doi.org/10.54174/UTJagr.Vo9.N1/03}

Tilmicosin

\section{5}

\begin{tabular}{l|l}
\hline 25 & 0 \\
$100 \%$ & $0 \%$
\end{tabular}

\section{Discussion}

Findings of colonies and the biochemical results were agreement with more than one authors like Gadi et al ., (2010); Ahmed et al ., (2014) and Quinn et al ., (2011) whom found same characters to P. multocida.

The primers discovering by Townsend et al .,. (1998) who reported the primer pair for all strains of P.multocida (serotypes A, B, D, E and F) and similar ,result recorded by Dey et al .,(2007) whom revealed the usefulness of PM-PCR in molecular identification of P.multocida isolates. In capsular PCR assay, 15 isolates from cow and 31 of buffaloes origin amplified a product of $760 \mathrm{bp}$ while rest of the cow and buffaloes isolates amplified a gene fragment of $1044 \mathrm{bp}$

$P$. multocida is normally found in upper respiratory tract of various animals, because its aerobic to facultative anaerobic, pleomorphic, non-spore forming; encapsulated and Gram-negative bacteria that are inhabitants of the upper respiratory tract of various animals but in experimental evidence has shown that under creation condition associated with debilitation, nutrition and climate factor, these organisms may singly or in concert with other organism flare up to cause severe infection with high morbidity and mortality (Dziva et al ., 2008), also it is an important cause of respiratory diseases and also it may be primary pathogens in H.S. or bovine resp. Disease or it may be play a secondary role in the pathogenesis of various diseases (Constable et al ., 2017) .

There are many studies were give same results on cattle and buffaloes .Also Gadi et al ., (2010) in marshes in south of Iraq who recorded and isolated the causative agent of outbreak of HS in buffaloes during 2008 then after bacterial . biochemical and histopathological characters, they proved the causative agent was $P$. multocida type $\mathrm{B}$ when isolated from lung. In addition Salah, (2012) on pathologic evaluation of $P$. multocida in Al-Qadisyia which found in her research that the cattle infected by the serotype $B$ which isolated from lung and nasal samples.

Virulence genes play a key role in disease production by bacterial pathogens. Among others, their functions include competence, adherence, synthesis, and export of capsules; and evasion of host immune responses (Nand uri et al ., 2009).

In the present study higher frequency of the virulence factors among isolates from buffaloes. Thus they are important role of these factors in disease occurrence. It was pointed out that virulence gene occurrence in $P$. multocida has a strong positive association with the outcome of infection with the organism in bovine (Katsuda et al ., 2013)

The study result nearly with (Khamesipour et al ., 2014) in Iran who they found the result in buffaloes ompA(90\%);hgbA (86\%) ; nanH(80\%); and pfhA(80\%) from result from slaughterhouse from 333 heads

Also with (Sarangi et al ., 2014) in India who they found hgbA (82.6\%); $\operatorname{nanH}(78.3 \%)$; and $\operatorname{pfhA}(95.7 \%)$

On the other hand occurrence of the virulence- genes in apparently healthy respiratory system could possibly 
ISSN Onlin:2708-9347, ISSN Print: $2708-9339$ Volume 9, Issue 1 (2020) PP 24-37

\section{https://jam.utq.edu.iq/index.php/main D Doi: https://doi.org/10.54174/UTJagr.Vo9.N1/03}

indicate early infection or contained infection which couldn't lead to disease. It was previously reported that this facultative anaerobic bacterium is commonly found in clinically healthy calves (Lainson et al ., 2013)

The study result agreement with (Kamran et al ., 2014) who found randomly distribution of virulence- genes between diseased and non-diseased when he study on 4 health buffaloes and 7 diseased positive to P. multocida from 400head.

Our result nearly from Khamesipour et al ., (2014) how found ompA(87\%)(100\%);hgbA (87\%)(100\%) ; $\operatorname{nanH}(87 \%)(80 \%)$; and pfhA $(82 \%)(100 \%)$ to for type $\mathrm{A}(32 \mathrm{head})$, and type $\mathrm{D}(5$ head) respectively. When they work on $P$. multocida isolated from cattle in Iran.

Also Sarangi et al ., (2014) how reported that hgbA (82.6\%);(82,3\%) ; $\operatorname{nanH}(78.3 \%)(82.3 \%)$; and pfhA(95.7\%)(94.1\%) to for Type A(5head), and Type B (17 head) respectively When they work on $P$. multocida isolated from buffaloes in India

The imprudent use of antimicrobials bears a high risk of selecting resistant bacteria, promoting the spread of resistance genes located on plasmids and transposons and consequently, reducing the efficacy of the currently available antimicrobial agents for the treatment of food producing animals. (Lion et al ., 2006)

The present study revealed that the isolates were $100 \%$ sensitive to the following antimicrobials is in conformity with the reports published by various researchers. They are Tilmicosin (McClary et al ., 2011;El Garch et al ., 2016) , Azithromycin (McClary et al ., 2011; Lion et al ., 2006) Cefitrixone Cefotaxime (El Garch et al ., 2016;) (100\%) then chloromphinocol between $96-92 \%$ (Al Shemari 2013 ) then tetracycline(40-32\%) and Ampicillin (32-28\%) (Kamienski and Keogh 2006)

The results of current study showing that no significant different between types of $P$. multocida and it response to treatment ,such observations were also reported by Khamesipour et al ..(2014); and McClary et al ., (2011)

\section{Conclusions}

1. P. multocida is endemic in buffaloes in south of Iraq.

2. Prevalence of virulence- genes appear ompA higher then hgbA then nanH and in last pfhA, and no significantly variation of prevalence of virulence- genes between infected and non-infected buffaloes.

3. The Pasteurella multocida best choice of treatment are Cefotaxime, Cefitrixone, Azithromycin and Tilmicosin

\section{Recommendations}

Production of vaccine from local isolated serotypes that contain different virulence genes and study the efficacy in laboratory and field animals. 
ISSN Onlin:2708-9347, ISSN Print: $2708-9339$ Volume 9, Issue 1 (2020) PP 24-37

https://jam.utq.edu.iq/index.php/main $\quad$ Doi: https://doi.org/10.54174/UTJagr.Vo9.N1/03

\section{V.References}

1. Ahmed ,W. A.; Al- Rubaei E. M. and Majeed, Sh. A. (2015) Prevalence of pasteurella spp. apparently healthy cattle and buffaloes herd in Baghdad governorate, Iraq. Al-Anbar J. Vet. Sci., .: 8.(1), 36-43.

2. Al-Shemmari I.(2013) Isolation And Molecular Identification Of P. Multocida From Cows And Buffaloes By Using Multiplex PCR Technique In Baghdad Province. Ph D. Thesis. Dept Of Internal And Preventive Medicine. College Of Veterinary Medicine. University Of Baghdad;.

3. Ara M.S; Rahman M.T; Akhtar, M; Rahman, M; Nazir, S; Ahmed, M.L; Hossen, M;Khan, F; Rahman, M. (2016), Molecular Detection Of Pasteurella Multocida Type B Causing Haemorrhagic Septicemia In Cattle And Buffaloes Of Bangladesh Progressive Agriculture 27 (2): 175-179

4. Bauer, A.W.; Kirby, W.M.M.; Sherris, J.C. and Turck, M. (1966): Antibiotic Susceptibility Testing Using A Stand ard Single Disc Method. Am.J.Clin. Pathol. 45:493-496.

5. Constable PD, Hinchcliff KW, Done SH, Grünberg W. (2017) Veterinary Medicine: A Textbook Of The Diseases Of Cattle, Horses, Sheep, Pigs, And Goats, $11^{\text {th }}$ Ed. Elsevier Ltd Co St. Louis, Missouri;. Pp. $2042-2050$

6. Dziva, F.; Muhairwa, A.P.; Bisgaard, M. And Christensen, H. (2008): lagnostic and Typing Options For Investigating Disease Associated With Pasteurella Multocida . Vet. Microbiol. 128(1-2):1-22 .

7. El Garch , F; De Jong, A; Simjee, S; Moyaert, H; Klein U, Ludwig C, Marion H, Haag-Diergarten S, RichardMazet A, Thomas V, and Siegwart E. (2016) Monitoring Of Antimicrobial Susceptibility Of Respiratory Tract Pathogens Isolated From Diseased Cattle and Pigs Across Europe, 2009-2012: Vet Microbiol. Oct 15;194:11-22.

8. Gadi, J. A. Al Amer, K. G. Abdullah, M. S. (2010). Diagnosis Of H.S. In Buffalos In Marshes Of South Of Iraq In 2008 Al-Qadsia J. Vet. Sci. 9(2):62-68

9. Kamienski, MARY And Keogh, Jim (2006) Pharmacology Demystified By The Mcgraw-Hill Companies $1^{\text {st }}$ Edi. Pp: $227-228$ 
ISSN Onlin:2708-9347, ISSN Print: $2708-9339$ Volume 9, Issue 1 (2020) PP 24-37

https://jam.utq.edu.iq/index.php/main $\quad$ Doi: https://doi.org/10.54174/UTJagr.Vo9.N1/03

10. Kamran ,M., M. Ahmad D., A. A. AnjumA. Maqbool, K. Muhammad, H. M. Khan, Hudda N., Nawaz ,M. and Ali, M. A.(2014) Antigenic Variation Among Pasteurella Multocida isolates From Diseased Buffaloes By Protein Profiling andCluster Analysis. Journal of Animal and Plant Sciences, 24(4):, Pp 1101-1109

11. Katsuda, K., Hoshinoo, K., Ueno, Y., Kohmoto, M., And Mikami, O. (2013). Virulence Genes and Antimicrobial Susceptibility In Pasteurella Multocida Isolates From Calves. Vet. Microbiol. 167,(3) 737-741.

12. Khamesipour ,Faham; Momtaz, Hassan and Mamoreh Morteza Azhdary (2014) Occurrence Of Virulence Factors and Antimicrobial Resistance In Pasteurella Multocida Strains Isolated From Slaughter Cattle In Iran. Journal Of Frontiers In Microbiology and Infectious Diseases. | 5 | Article 536 Pp:1-9

13. Lainson, F. A., Dagleish, M. P., Fontaine, M. C., Bayne, C., and Hodgson, J. C. (2013). Draft Genome Sequence Of Pasteurella Multocida A:3 Strain 671/90. Genome Announc. 1, E00803-E00813. Doi: 10.1128 /Genomea.00803-13

14. Lion, C; Conroy, M.C.; Carpentier, A.M,; Lozniewski, A.( 2006) Antimicrobial Susceptibilities Of Pasteurella Strains Isolated From Humans Int J Antimicrob Agents. 27(4):290-293.

15. Mc-Clary, DG,; Loneragan, GH,; Shryock, TR; Carter, BL,; Guthrie. CA, ; Corbin MJ,; Mechor, GD.(2011) Relationship Of In Vitro Minimum Inhibitory Concentrations Of Tilmicosin Against Mannheimia Haemolytica and Pasteurella Multocida and In Vivo Tilmicosin Treatment Outcome Among Calves With Signs Of Bovine Respiratory Disease J Am Vet Med Assoc.;239(1):129-135

16. Nand uri, B., Shack, L. A., Burgess, S. C., and Lawrence, M. L. (2009). The Transcriptional Response Of Pasteurella Multocida To Three Classes Of Antibiotics. BMC Genomics 10:S4 Doi: 10.1186/1471-216410-S2-S4

17. OIE.(2012): Principals Of Veterinary Vaccine Production. In: Manual Of Stand ards For Diagnostic Tests and Vaccines For Terrestrial Animals. Seventh Edition: ISBN 978-92-9044-878-5 .1: Haemorrhagic Septicaemia. Pp 732-740

18. Quinn ,P. J. , B. K. Markey , F. C. Leonard , P. Hartigan , S. Fanning , E. S. Fitzpatrick (2011) Veterinary Microbiology and Microbial Disease (Second Edition) 2 (2015), Wiley - Blackwell Publishing Pp. 300-309

19. Salah NJ.( 2012) Isolation And Diagnosis Of Pasteurella Multocida From Cattle And Sheep And Serotype Classification By Using Polymerase Chain Reaction. Mvsc Thesis. College Of Vet. Medicine / University Of Al-Qadisiyah;

20. Sarangi,L. N. ; Adyasha P.; Santosh K., ;Prasad, T.; Santosh Kumar Gupta.(2014) Virulence Genotyping Of Pasteurella Multocida Isolated From Multiple Hosts From India . Scientific World Journal ., Article ID 814109, 10 Pp:299-304

21. Townsend, K.M., Frost.A.J., Lee.C.W., Papadimitriou.J.M., and Dawkins.H.J.S., (1998): Development Of PCR Assays For Species and Type Specific Identification of $P$. Multocida Isolates Journal Of Clinical Microbiology, 36:1096-1100. 